\title{
Addressing the Accountability Challenges of International Policing in Peace Support Operations ${ }^{*}$
}

\author{
Jonathan A Kearney, Sofia Botzios and Tom B Hadden**
}

\begin{abstract}
There is increasing concern over the behaviour and accountability of international personnel, including CIVPOL contingents, deployed in peace-keeping and peace-building missions throughout the world. From the point of view of local populations the 'internationals' are typically perceived to be 'above the law'. This is directly related to the fact that under status of forces or mission agreements (SOFAs or SOMAs) they are exempt from local host state jurisdiction. There are also significant practical problems in gathering and presenting evidence for disciplinary or criminal proceedings in their home states. This paper will analyse these problems in detail, based on a study of some recent European Union and international missions and suggest how a more co-operative home and host state approach to monitoring, investigation and adjudication of alleged misconduct might achieve more effective accountability and thus contribute to the overall success of CIVPOL missions.
\end{abstract}

\section{Introduction}

International peacekeeping could be described as a growth industry at the turn of the twenty-first century. Peace Support Operations (PSOs), as peacekeeping missions are known, embrace a variety of activities such as conflict prevention, peacemaking, peace enforcement, peacekeeping, peace-building and humanitarian operations. ${ }^{1}$ This work has traditionally been conducted by the military, however, more recently policing has adopted a stronger role, supported by an element of civilian activity aimed at institutional reconstruction. Given that PSO activity is in response to a conflict environment, the involvement of civilian policing activity may not always be possible where the intensity of the conflict is at its greatest. That said, international policing is attracting increasing attention from researchers and analysts as PSOs develop in the wake of the end of the cold war and the creation of a new world order and police assume an increased role in these operations.

Policing at this international level pushes the boundaries of traditional conceptions and debates as to the function, role, accountability and governance of the

\footnotetext{
* This article draws on and supplements material from Hadden [29].

**Jonathon Kearney, doctoral student Queen's University Belfast, Sophia Botzios, researcher Queen's University Belfast, Tom Hadden, Professor of Law, Queen's University Belfast and University of Ulster.

${ }^{1}$ The United Kingdom's military doctrine defines a Peace Support Operation as 'an operation that impartially makes use of diplomatic, civil and military means, normally in pursuit of United Nations Charter purposes and principles, to restore or maintain peace. Such operations may include conflict prevention, peacemaking, peace enforcement, peacekeeping, peacebuilding and/or humanitarian operations.' Additional doctrinal definitions can be found in The Military Contribution to Peace Support Operations [37: 1-2].
} 
police. Bayley and Shearing, describing policing as the activity of making societies safe, highlight that it is no longer carried out exclusively by governments [7: 1]. Whilst they are speaking primarily of the domestic experience within nation states, their assertion can be applied to policing being delivered in the international context - circumstances where police officers or experts from outside the jurisdiction or nation state that is the focus of the operation are deployed to substitute for some or all of the activities of the indigenous police or to monitor, mentor or advise the local police's ongoing activity. ${ }^{2}$ Those deployed may not actually be police officers in the sending states, but employees of contracting companies that provide a specific range of services through the outsourcing of military or policing activity by a sponsoring state. International policing must also be distinguished from the transnational variety, which has been the subject of much debate in recent years [26: 11-15]. Grieve et al take up this task, suggesting that international policing has two broad manifestations:

i. Within PSOs, under the auspices of international organisations such as the United Nations (UN) or the European Union (EU), coalitions of the willing or at the invitation of a national government.

ii. Assistance and training aimed at enhancing specific capabilities in the host nation's police [28: 49].

Transnational policing, from their perspective, is the investigation of cross-border criminality offending national criminal laws by domestic police agencies either individually or in joint operations with agencies from other national jurisdictions [28:49]. In transnational policing then, the officers will still be operating in the interests of their home state, even if their work has an effect in the host state. In international policing, they operate in the interests of the host state, as representatives of their home state (or the UN or EU).

Achieving accountability of police services in their domestic environments presents significant challenges. These challenges are enhanced at the transnational level but are multiplied even further when officers are deployed on international missions to unfamiliar and challenging environments, where questions arise as to who has legal jurisdiction over the officers [30: 46]. Further, at this level accountability need not be

\footnotetext{
2 Substitution, monitoring, mentoring and advising describe the European Union's response to civilian crisis. Hartz termed the experience within the UN context as being SMART activity - Supporting human rights, humanitarian assistance; Monitoring the performance of the local law enforcement agency, prisons, courts and implementing agreements; Advising the local police on humane effective law enforcement, according to international standards, laid down in the various human rights instruments (treaties, covenants, conventions and charters); Reporting on situations and incidents; Training the local law enforcement in best practice for policing and human rights, see Hartz [31:31]. Replacement of the indigenous police in some or all of its activities is termed executive policing from the UN perspective; see Dwan [20].
} 
viewed solely as a means for legal and disciplinary redress but also as a way of informing best practice and promoting organisational learning across participating states [25: 1]. There has been general concern in recent years over both mission-related and off-duty conduct by some members of international contingents during PSO missions. This has often focused on their involvement in various forms of sexual abuse of the local population ranging from rape and other sexual assaults to the encouragement of prostitution and drug trafficking. But the problem extends to other ways in which international personnel can take advantage of their privileged position. Some abuses are clearly contrary to the law of armed conflict or would amount to criminal offences under both host and home state laws, but the formal status of other actions is less clear. Conduct that would involve the violation of international human rights, for example, does not necessarily constitute a criminal offence on the part of the individuals concerned. Financial corruption, verbal abuse and incivility in their dealings with the local population, whilst distasteful and unprofessional, may not be unlawful. And the internal disciplinary codes of military and police contingents may differ across the range of sending countries.

Combined, these problems have served to impede holding officers to account, creating an impression within host states that such officers are 'above the law' raising questions as to the legitimacy of these missions. This is the focus of this paper which will begin by establishing the context of these accountability issues. The scale of PSOs and their composition will be discussed from data available from both the UN and the EU, as well as the problems of misconduct which are known to exist. The core of the paper will then focus on how accountability and governance in such scenarios can operate or fail to operate. This will involve discussion of the applicable international standards, individual legal accountability, institutional accountability, state legal responsibility and political accountability, each of which is relevant at this level. Possible reforms will be examined at the conclusion of the paper.

\section{The Growth in International Policing Activity}

\section{The United Nations}

A cursory check of the United Nations Department of Peacekeeping Operations (UNDPKO) website reveals the almost exponential growth in peacekeeping operations since the initial deployment of United Nations Truce Supervision Organization (UNTSO) in May 1948. A total of 63 missions have been launched in the past 61 years and there are currently $15 \mathrm{UN}$ operations, nine of which have a policing element. This accounts for a total of 12,222 police officers coming under the banner of the UN Police Division 
(UNPOL). With such scales of deployment, UNPOL is regarded as the fastest growing component of UN peacekeeping [66].

The UN focus is frequently on the less benign policing environments and strength of policing numbers is the order of the day creating a demand for the large numbers of the Formed Police Units (FPUs). FPUs are specialised, well-equipped and fully mobile rapid-reaction police or other law enforcement agency units. They are generally comprised of one hundred and twenty-five members each, composed entirely of elements from one contingent. They are deployed on UN missions as cohesive units and are selfsustaining in terms of equipment. FPUs will operate in line with criteria established under a Memorandum of Understanding between the UN and the Police Contributing Country [66].

The concept of the FPU is by no means the sole preserve of the UN: it has been embraced within Europe, the home of the gendarmerie. Progress and development in the arena of gendarmerie forces arose from the G8 Sea Island summit in 2004 with the development of an action plan for expanding global capability for PSOs [24]. Proposed by the Italian government, the resulting Centre of Excellence for Stability Police Units (CoESPU) was established and co-located with the European Gendarmerie Force (EGF) headquarters at the barracks of the Italian Carabinieri (the Italian gendarmerie) in Vicenza, Italy. One of the aims of the programme is that trainees will become the nucleus of gendarmie-like peacekeeping forces in their respective countries, with a particular focus on African countries. The centre will also develop doctrine and common operational procedures for the employment of gendarmerie type forces in Peace Support Operations [1]. CoESPU is supported by the G8 nations and is independent of EU control. ${ }^{3}$ The EGF, however, is primarily at the disposal of the EU to carry out police missions in crisis management operations, in accordance with the principles set up in Santa Maria de Feira and Nice European Council conclusions [22]. In these circumstances, the Political and Security Committee of the EU (PSC) assumes the political control and the strategic direction [22]. The EGF role is not limited to EU activity: its services can also be put at the disposal of the UN, Organization for Security and Co-operation in Europe (OSCE), North Atlantic Treaty Organisation (NATO), other international organizations, or an ad hoc coalition [22].

International missions, particularly those associated with the UN, bring together an eclectic mix of individuals from disparate backgrounds and with varying experiences.

\footnotetext{
${ }^{3}$ The G8 nations comprise France, Germany, Italy, the United Kingdom, Japan, the United States of America, Canada, and Russia.
} 
With such a variety, the professionalism and ability of the officers can range from impressive to incompetent. The unevenness in the quality of international police officers has been a recurring theme in discussions of the subject with an almost monotonous regularity $[9,42-44]$. An examination of those nations making the highest numerical contributions to UN missions provides some interesting revelations, with four of the top contributors categorised by the UN as being least developed countries [54]. UN missions are particularly attractive to officers from such nations because of the financial and other benefits which can be accessed [2]. Participation in UN missions on the parts of police officers from developing nations can bring significant salary increases. Anecdotal accounts exist of corruption at national levels to ensure that officers are chosen for, or remain in, such missions as the potential financial benefits of involvement can represent once in a lifetime opportunities for the successful applicants to change their own financial circumstances. The opportunities that are then presented to corrupt or unscrupulous individuals to amass further wealth through criminal exploits or corrupt activity are not to be underestimated. With police occupying a position of power and control that sets them apart from the ordinary citizen it is imperative that they can be trusted to exercise that power and control within boundaries that accord with professional best practice democratic accountability [27]. The transitional circumstances in which police missions deploy often represent the engrafting of democratic principles in the aftermath of the demise of totalitarian, despotic or otherwise corrupt regimes and there can be a struggle to ensure that the new ideals are reflected and upheld [38]. There is then, a double challenge to the mission; first in terms of educating the host population that the police provide a service for the protection of the citizen rather than security of the state, and second within the mission itself where some officers are ill equipped, poorly qualified with policing experience which finds no basis in human rights compliance. Hansen's view is that this will continue to be the case whilst the desire to appease some developing or non-democratic countries' interests outweighs the concern for deploying an effective and credible police mission [30]. 


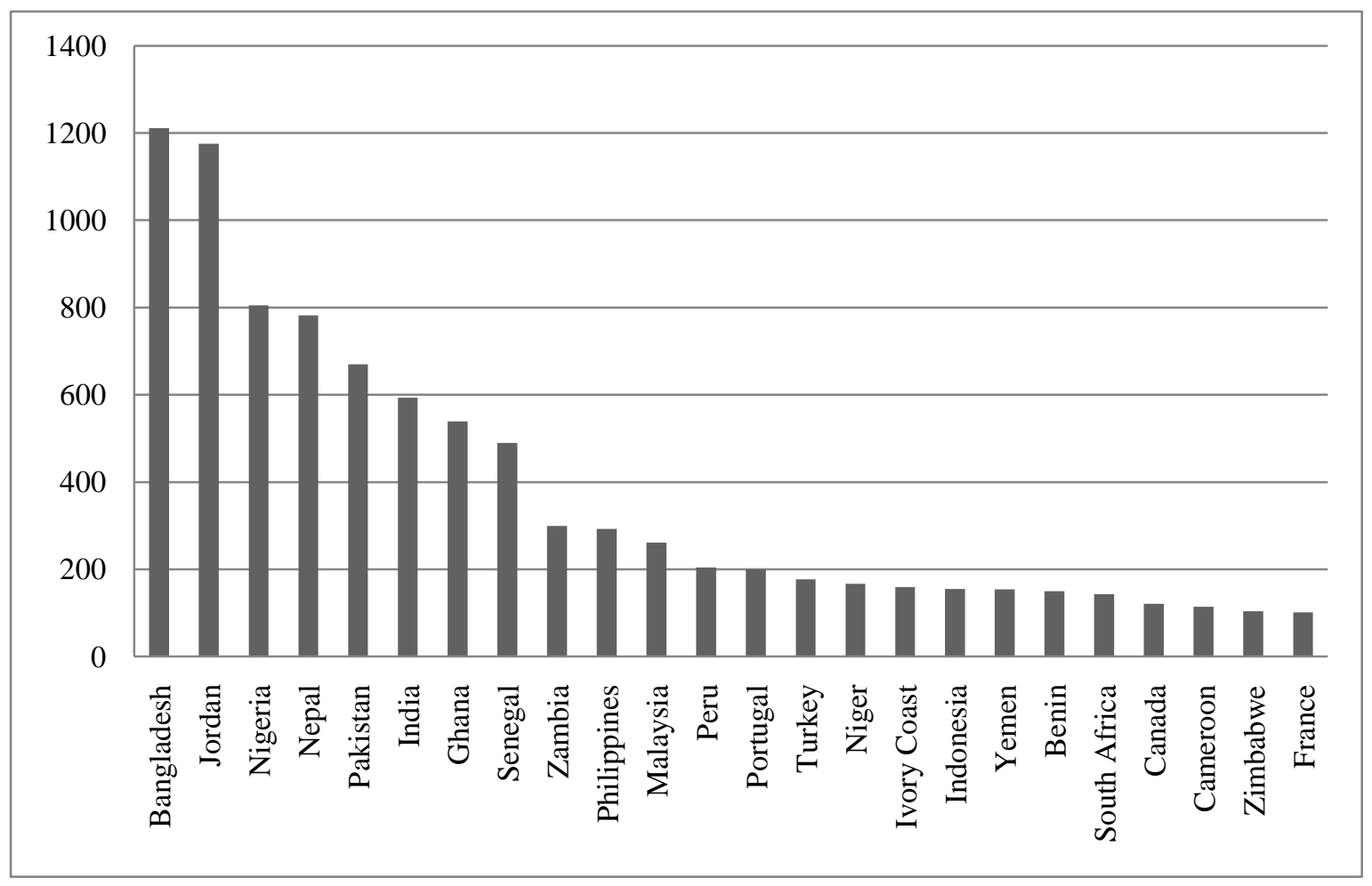

Figure 1: Top contributors of police to UN Peacekeeping Operations 2009 [50].

Hills suggests that because of difficulties in recruiting suitable officers from Western democracies, UNPOL missions are usually filled by police from countries with records of brutal or corrupt practice [32: 63]. With the exception of Canada, France and Portugal, some of the countries identified in Figure 1 might be considered as having dubious human rights records or not being repositories of the best democratic policing practice on offer. Hills further describes the mixed impact of the police officers within UN peacekeeping: the missions witness a combination of altruism, firefighting, reform and opportunism and within such scenarios, some multinational police have sought to bring stability and enforce peace while others have exploited the opportunities for more personal (usually sexual) forms of gratification [32: 63].

Whilst primarily related to military personnel, the UN has recently acknowledged the fact that dozens of its peacekeepers involved in cases of sexual abuse and exploitation have been disciplined and punished. Since January 2009, 33 military personnel implicated in such cases while serving in UN operations have been disciplined and punished. Punishments have included forced retirement, withdrawal of officers' commissions, various lengths of imprisonment and dismissal. Two military personnel received such disciplinary action in 2008 and there were 15 such cases in 2007 . Over the past three years, disciplinary action was initiated against 20 military personnel for cases involving a variety of forms of misconduct, such as negligent loss of firearms, traffic- 
related violations and fraud or theft [47]. With an excess of 90,000 police and troops deployed in 15 missions throughout 2009, the disciplining of 33 soldiers could not be considered as making a substantial impact on the identified wrongdoing or the temptation to others to become involved in such activity. The fine detail in relation to the sending nations of these officers and the breakdown of cases is not available and the UN acknowledges that it can only pursue cases of any misconduct to a particular stage with national tribunals and national courts having a role to play.

Even though the UN encourages troop contributors to do more in prosecuting and punishing their nationals who engage in misconduct, the results are not impressive, as displayed by Table 1. These limited responses serve only to fuel the discontent felt by victims of crime and wrongdoing and the concerns of NGOs. They further highlight that accountability mechanisms fall far short of acceptable standards and that the system requires major overhaul. It is only by such an effort that any degree of confidence would be restored in the UN's ability to perform its various roles.

\begin{tabular}{|l|l|l|l|}
\hline Year & Requests & Responses & $\begin{array}{l}\text { \% } \\
\text { Success }\end{array}$ \\
\hline 2007 & 146 & 9 & 6.3 \\
\hline 2008 & 192 & 6 & 3.1 \\
\hline 2009 & 112 & 14 & 12.5 \\
\hline
\end{tabular}

Table 1: UN Requests to Troop Sending Nations for Punishment or Prosecution of personnel involved in misconduct [48].

The figures represented by Table 1 relate to the activities of military personnel deployed on peacekeeping activity. Given that the numbers of soldiers deployed are well in excess of police officer totals (police components of UN peacekeeping missions were in the region of $12 \%$ throughout 2009) and the overall success rate in holding soldiers to account is low, the challenge of holding a smaller population of police officers to account is even greater.

\section{The European Union}

The OSCE has seven police related missions which aim to conduct and coordinate the protection of participating states from risks and challenges posed by transnational and organised crime (trafficking in drugs, arms and human beings), failure to uphold the rule of law and human rights violations. The EU has 10 crisis management missions with a police component where the aims are broadly to monitor, mentor and 
advise from a support perspective and within the context of local ownership. The policing element of European missions, conducted within the context of the European Security and Defence Policy, falls within one of the four pillars of Civilian Crisis Management: strengthening (advising, assisting and training) and substituting for local police forces.

\begin{tabular}{|l|l|}
\hline Mission & $\begin{array}{l}\text { Police/Criminal/ } \\
\text { Intelligence Experts }\end{array}$ \\
\hline EUPM BiH & 2 \\
\hline EULEX Kosovo & 1,087 \\
\hline EUPOL Copps & 13 \\
\hline EUBAM Rafah & 2 \\
\hline EUJUST Lex & 6 \\
\hline $\begin{array}{l}\text { EUSSR Guinea } \\
\text { Bissau }\end{array}$ & 4 \\
\hline EUPOL RD Congo & - \\
\hline EUMM Georgia & 245 \\
\hline EUPOL Afghanistan & 168 \\
\hline TOTAL: & $\mathbf{1 , 5 2 7}$ \\
\hline
\end{tabular}

Table 2: Deployment of Police Officers, Criminal and Intelligence Experts on EU Missions [12].

The European operations have not been on the same scale as recent UN operations in terms of the total numbers of officers deployed, an indication that despite the challenging nature of some of the scenarios in which the EU tends to become involved, they may not require the same large scale deployments of personnel. This is not to detract from the EU's declared aims at the conclusion of the Feira European Council in Portugal in June 2000 that included targets for the development of police capabilities [21]. These targets represented a significant move within the EU in international policing terms:

1. The ability to provide up to 5,000 police officers to international missions;

2. The ability to rapidly deploy up to $1,000^{4}$ police officers within 30 days for monitoring, advisory, training and executive missions.

3. The development of robust, rapidly deployable, flexible and interoperable EU integrated police units [14: Appendix 4].

The above discussions show how the numbers of personnel involved in international policing missions are substantial, that circumstances in which corrupt behaviour could occur exist and that problems are prevalent in terms of holding them to account for their

\footnotetext{
4 The figure of 1,000 later became 1,400 as a result of undertakings given at the Police Capabilities Commitment Conference [14].
} 
actions. To this end the paper will now turn to consider the various accountability standards and mechanisms which could be relevant and how these operate in an international policing context.

\section{International Expectations and Generic Standards}

The UN's first direct attempt at codifying the behaviour of criminal justice personnel was the publication of the Compendium of United Nations Standards and Norms in Crime Prevention and Criminal Justice in 1992 (updated in 2006). The compendium, as the name suggests, was a repository of standards, norms, instruments, conventions and protocols rather than a code of conduct. With the increasing UNPOL deployments the UN produced the Blue Book in 1999, which draws upon international standards and norms to address the basic principles of criminal justice, human rights and humanitarian law for the guidance of the civilian police components of peacekeeping operations. ${ }^{5}$ A distillation of the content of the Blue Book informs the range of obligations - a code of conduct - for police officers which addresses corruption, acting for personal gain, sexual exploitation and criminal behaviour in its nine points [55]. The definitions of serious and minor misconduct elaborate on some of the content of the more outward facing obligations and provide additional detail in relation to internal discipline [51]. The UN took steps towards the imposition of more general and consistent standards for all international personnel in 2000 with the adoption of Security Council Resolution 1325 on Women, Peace and Security. The resolution sought to encourage the mainstreaming of a gender perspective into all peacekeeping operations, including specialised training for all personnel on the protection, particular needs and human rights of women and children in situations of conflict [61].

Police officers are regarded as 'experts performing missions' for the UN by virtue of Article VI of the 1946 Convention on the Privileges and Immunities of the United Nations [56]. Such a status affords them functional immunity for the purposes of the official acts they perform. This functional immunity enables them to act within the mandate of the mission but they remain subject to local civil and criminal law of the host country for illegal acts committed that do not form part of their official functions. The Secretary-General has the right and the duty to waive the immunity of any individual in any case where, in his opinion, the immunity would impede the course of justice [53].

\footnotetext{
5 The subjects of arrest, force and firearms, trials, victims, detainees and prisoners, torture and other cruel treatment, illegal executions, genocide, humanitarian rules and refugee protection are addressed in the document.
} 
A recent UN working paper on the Accountability of International Personnel

Taking Part in Peace Support Operations reached the following conclusion:

Transparent accountability for disciplinary offences is important. If it is perceived that the alleged authors of misconduct are left unpunished that may undermine the credibility of the mission itself. It is particularly important where the misconduct has an impact on the host population and where they regard the misconduct as criminal in character [62].

This perception is often borne out by what actually happens when those involved in abuse both on and off duty are returned to their home countries. In the case of military and police personnel there will typically be an investigation into the incident and consideration of whether criminal charges - whether before a military court martial or an ordinary criminal court - or internal disciplinary procedures should be pursued [10]. In either case there will often be difficulties in securing evidence from witnesses in the country of deployment and in a large proportion of cases the potential charges will be dropped or those charged will be acquitted.

Following on from the UN Security Council Resolution 1325, the European Union developed a series of documents with a view to setting more general standards of conduct for all EU missions. In 2005 a set of Generic Standards of Conduct was agreed, drawing on a civilian code of conduct for those involved in the Althea mission in Bosnia [15]. This was followed in June 2006 by the production of general guidelines on Mainstreaming Human Rights in ESDP Missions [17]. In November 2006 a set of Conclusions on Gender Equality and Gender Mainstreaming was promulgated [16]. Each of these documents is intended to apply to all personnel involved in EU missions and to establish more demanding standards of behaviour than those imposed under international armed conflict or human rights law. The Generic Standards include not only a statement of the standards of conduct expected at all levels of the mission but also provisions and procedures for their implementation by mission commanders. The documents on Mainstreaming Human Rights and Gender Equality are directed at a somewhat higher level with a view to influencing both the general strategies for each mission and the way in which they are to be implemented on the ground. Mainstreaming human rights in any mission will involve the development of procedures at command level to plan for and monitor the impact of the operation on the full range of human rights of the local population and thus the inclusion of human rights advisers and field officers in central and local command centres. Mainstreaming gender issues will likewise require both advance planning for and regular review of the impact of the mission on the involvement 
and protection of women and children not only from the conflict itself but also from the risk of sexual and other forms of abuse by mission personnel.

These general formulations of the principles to be followed in all EU crisis management missions and the rules of conduct for all those involved are clearly significant. They provide an important framework for policy makers and police commanders in planning and carrying out crisis management interventions. The Generic Standards also provide a useful basis both for training in advance of deployment and for the management and monitoring of the activity of all personnel on the ground. But there are nonetheless some significant difficulties and weaknesses in their implementation and impact.

Part of the problem stems from the established principle that any enforcement or disciplinary action for military and police personnel is a matter for the authorities in the home country rather than the mission commander. The wording of the relevant provision is precise:

With regard to military and civilian personnel, seconded in the framework of the operation, by Member States, Third States or EU Institutions, relevant national authorities or relevant authorities within the EU Institutions will retain full disciplinary jurisdiction over their personnel. [16: 11]

This makes it difficult for consistent and effective measures to be applied to all those involved in the mission. The provisions in respect of reporting 'serious instances' of misconduct reflect this fragmentation of responsibility. It is not clear what disciplinary measures are to be imposed either for criminal activities or for human rights violations, nor is it clear to whom the reports referred to in the document are to be sent or what action is to be taken in respect of any failure on the part of national authorities to apply the standards.

The primary source of authority for mission commanders and personnel lies in the formal mandate and rules of engagement for the mission. If these documents do not include express authority to take action to enforce the relevant standards, there may be an inability to intervene to deal adequately with serious breaches by mission personnel. The result may be that all that can be done is to report the violations without taking any action to prevent them.

Therefore, the general documents setting out the standards to be observed in all missions need to be supported by effective procedures to ensure compliance. This points to two closely linked issues of accountability: 
- the individual accountability for carrying out or not preventing any form of abusive behaviour, whether or not it threatens the success of the mission;

- the institutional accountability of those who initiated or planned the mission whether for setting unachievable objectives or for failing to carry it through to successful completion.

Attention has generally been focused on the first of these and on the widely recognised deficiencies in the way in which those responsible for serious abuses have often been handled. But, just as in domestic police forces, it is equally important to create structures to identify and deal with failures at more general levels of planning and implementation. EU missions are undertaken on behalf of the people of the Member States and there is a need for effective democratic accountability for what is achieved or not achieved in their name. Moving on from these notions of accountability, we encounter state legal responsibility and political accountability. A hierarchy of accountabilities then exists from the individual through to the institution and on to the states that comprise the institution, with the wider political domain being the final arena of accountability.

\section{Individual legal accountability}

The importance of establishing good relations with the local population and preventing any form of abuse is recognised as a key to the success of missions [19, 63]. However, the procedures for dealing with cases of abuse are exclusively the responsibility of the authorities in the home states of those concerned and the procedures for reporting and disciplining those responsible by mission commanders are relatively weak [51]. Minor incidents and abuses can be dealt with by internal disciplinary procedures within a substantial national contingent. More serious incidents or allegations of abuse typically result in those responsible being sent back to their home country to await the results of an investigation and a decision on whether criminal or disciplinary proceedings are to be taken. This is clearly understood by those deployed in missions who may feel under less risk of being called to account for abusive or potentially criminal conduct than in their home jurisdiction. The result from the point of view of the local population is the appearance - and often the reality - that members of international missions are above the law and that complaints are not treated seriously. This does not contribute either to the maintenance of good relations or to the success of the mission. Dealing with this problem and developing more effective mechanisms requires a more detailed analysis and understanding of the formal and practical reasons for this established pattern. 
At a formal level, the immunity of mission personnel from any legal proceedings in the country of deployment stems from the assimilation of their status to that of diplomats. They have always been entitled to full diplomatic immunity on the ground that it is essential to the maintenance of international relations and that they do not generally pose any threat to the country in which they work [18: 203]. The initial UN peacekeeping forces deployed in the 1950s and 1960s benefited from a similar form of immunity under what became known as Status of Forces Agreements (SOFAs) or Status of Mission Agreements (SOMAs). This approach has become standard practice for both the UN and the EU. In recent years it has been gradually expanded to cover not only regular military and police personnel but also those working as contractors, though immunity for these is generally restricted to activities within the terms of the contract. In the case of contractors there may be additional difficulties in respect of whether any national agency has the authority or capacity to carry out an investigation and whether there is jurisdiction for the courts to deal with any criminal charges. There is a general trend to include private security contractors in the formal provisions for immunity from legal proceedings in the country of deployment [34]. But in many cases the military contingents that employ them have no authority to deal with any abuses in military courts. All that may happen in such cases is that the suspect is dismissed from employment.

The Kathryn Bolkovac case, where an officer who attempted to blow the whistle on trafficking and sexual assault had her employment terminated, provides a stark illustration of the accountability deficit coupled with a mindset that erases the problems through termination of employment rather than through appropriate procedural accountability and legal process. ${ }^{6}$ One International Police Task Force (IPTF) Commissioner acknowledged that, '[t]here were truly dreadful things going on by UN police officers from a number of countries,' suggesting that there were police officers there who should not have been [4]. The United Nations Mission in Kosovo (UNMIK)

\footnotetext{
6 Ms K Bolkovac v DynCorp Aerospace Operations (UK) Ltd [2002] case no. 3102729/01. $<$ http://www.contractormisconduct.org/ass/contractors/59/cases/688/765/veritas-capital-dyncorp-inbosnia_bolkovac-decision.pdf > accessed 18 November 2009. A former police officer from Nebraska, where she had experience and expertise in cases involving child abuse and sexual assaults on women, Bolkovac was employed in 1999 as a police monitor for the IPTF in Bosnia and Herzegovina (BiH) by a London-based subsidiary of DynCorp, a major US Private Military Company. She became concerned about the extent of the trafficking of women and girls by organised criminals for prostitution in $\mathrm{BiH}$ and the involvement of UN Personnel. The issues were drawn to the attention of her IPTF superiors, many of whom were IPTF and DynCorp employees. In 2001 her contract of employment was terminated on the grounds of inaccurate completion of her timesheets. As she had been employed by a UK based company, she brought her case to an employment tribunal in the UK and the tribunal found that her dismissal was because of her whistle-blowing activity rather than as a result of procedural irregularity within the terms and conditions of her employment.
} 
also had its share of opaque accountability as illustrated by the cases of Martin Almer ${ }^{7}$, where home authorities assisted him in avoiding prosecution in Kosovo, and the Vetëvendosje demonstration where two protestors were killed but the international forces escaped sanction. ${ }^{8}$

In the case of contractors, there may be additional difficulties in respect of the authority or capacity of any national agency to carry out investigations and whether there is jurisdiction for the courts to deal with criminal charges. ${ }^{9}$ Given the poor record for successful prosecutions of alleged offenders in their own domestic courts [67], the general conclusion must be that some changes in the current legal regimes in both national and international law are essential if there is to be effective accountability for crimes and other abuses committed by international personnel during any form of peacekeeping or crisis management intervention [29: 112-113].

The shortcomings of the current accountability mechanisms contribute to the perception of impunity and the alienation of the local population given that very little of the investigation or trial proceedings are located in the area where the incident took place and, even if a judicial sentence or disciplinary sanction is eventually imposed, the result may not become apparent to those most directly involved. Additionally the local population often fails to achieve effective accountability and justice because of the reduced chances of a conviction through lengthy delays as evidence is gathered and transmitted to the home state. The fact that judges or juries are so far removed from the area of deployment further limits the likelihood of a full understanding of what occurred.

One important consideration in favour of retaining the established structures is that dealing with incidents under the host state's laws and procedures could prejudice the

\footnotetext{
${ }^{7}$ Austrian police officer, Martin Almer, serving with UNMIK, was charged in Kosovo for ill treatment and causing minor physical injuries for the purpose of extracting a confession during the course of duty. UNMIK took measures to withdraw his immunity and he was eventually tried in absentia by Orahovac Municipal Court. However, the Austrian authorities facilitated his evacuation on the premise that he was psychologically ill. This case led to disputes between UNMIK and the Austrian authorities on jurisdiction and was covered widely by the Kosovo media, leaving the impression locally that 'internationals' were above the law [39].

${ }^{8}$ Two Kosovo Albanians were killed and two others were seriously injured during a nationalist demonstration in Pristina in February 2007 organised by the Vetëvendosje (self-determination) organisation. Members of a Romanian Formed Police Unit (FPU) performing duty at the demonstration opened fire on the demonstrators using rubber bullets. The British UNMIK Police Commissioner resigned in the immediate aftermath of the incident and within a matter of weeks, the members of the FPU had been repatriated to Romania. An UNMIK investigation, overseen by the Police Inspectorate of Kosovo, attributed responsibility to the Romanian unit but was unable to identify the individual officers responsible $[48,36]$.

${ }^{9}$ In the USA, the Military Extraterritorial Jurisdiction Act of 2000 was powerless to deal with military contractors whose role was not part of a (US) Department of Defense mission. Subsequent Bills to address the shortcomings - MEJA Expansion and Enforcement Act of 2007 [40] and Transparency and Accountability in Security Contracting Act of 2007 [47] had not been enacted by the end of the two year Congressional term and so were removed from the books. The Transparency and Accountability in Security Contracting Act of 2009 is currently making its way through committee in Congress, although the declaration that the majority of bills and resolutions never make it out of committee does not inspire long term confidence that the demands of accountability will be met.
} 
chances of a fair trial or hearing for those accused of misconduct. This is closely aligned with the reluctance of contributing states to deploy their police or armed forces if they do not qualify for immunity. Nonetheless some changes in the current structure will be needed to ensure better preventive control of potential abuses and effective accountability of all international personnel, both at command and lower levels, and thus maximise the acceptability and effectiveness of international peacekeeping and crisis management. This will involve realistic balancing of the requirements of most Member States for home state accountability and the practicalities of involving host state authorities insofar as is possible in the formal procedures.

In terms of effective prevention the main responsibility must be on both the chain of command and the pre-deployment preparation and training of all those involved [30: 57-60]. Though the importance of prevention as the best approach to potential abuse is generally recognised, there are some significant deficiencies in the formal procedures for ensuring that it is implemented at all levels. Within an EU context, there is currently no clear requirement for the reporting of incidents from national contingents to central command, with the result that actual or potential abuse can be concealed or condoned in the interests of national reputation or self-esteem. The development of a comprehensive and effective system for reporting all incidents and associated risk assessment would help to emphasise the importance of the prevention of all forms of abuse to the success of every mission. It may also assist to incorporate and highlight the concept of command responsibility for the prevention of abuse in all relevant mission mandates and rules of engagement. Where possible, representatives of the local authorities and population should be involved at least in preventive measures and monitoring and wherever possible in judicial proceedings.

\section{Institutional accountability}

The focus in respect of individual accountability is on the prevention and control of abusive conduct. It is equally important, however, to ensure that there is effective oversight and accountability for those who make strategic decisions both in deciding on deployments and in carrying them out. This not only involves responsibility for strategic decisions on the use of different forms of police or military power but also more general assessments of the success or failure of missions.

At this level it is often difficult to identify particular individuals since decisions are made on a collective basis, especially those made within the EU through direct involvement of large numbers of member state representatives. As a result, responsibility and accountability must often be approached on an institutional rather than an individual 
basis. This is recognised in most areas of human rights law and international law under which it is the state or a public body which is held responsible for breaches or violations [45: 778-79]. Except in respect of the most serious international crimes subject to the International Criminal Court and similar bodies, the responsibility of the individuals involved in these collective decisions is in practice dealt with in a political rather than a legal context. ${ }^{10}$

\section{State legal responsibility}

Participating states in crisis management missions, and potentially also the EU itself, are clearly responsible for human rights violations and abuses under the European

Convention on Human Rights, for violations of the law of armed conflict under the Geneva Convention and Protocols and for other violations of international law [18: 244]. In current circumstances, however, given the uncertain status of the EU under these conventions, the primary responsibility is on the individual participating states.

The most significant of these in practical terms for the relevant states is the potential liability under the European Convention on Human Rights since individual complaints can readily be made. There is no equivalent procedure for raising alleged breaches of the law of armed conflict under the Geneva Conventions and Protocols and there is no international court or tribunal with specific jurisdiction to make rulings on state violations. The primary responsibility for dealing with alleged violations by individuals rests with the home state of those under suspicion. Allegations of violations of general international law, including obligations under international human rights and humanitarian law conventions, can be raised by other states before the International Court of Justice. But in such cases there are typically difficult issues of jurisdiction to be surmounted and in the light of experience of recent judgements in matters of this kind there is often a lack of clarity on the eventual outcome. ${ }^{11}$

Despite the ease with which cases can be raised, there are also some difficulties in establishing state liability under the European Convention on Human Rights. The underlying principle is that each European state is required to guarantee the specified human rights of all those on its territory. Whether this extends to an obligation on states participating in crisis management missions to comply with the Convention in the

\footnotetext{
${ }^{10}$ The UN sponsored investigation into violations of IHL and HRsL that might have been committed within the context of the military operations that were conducted in Gaza during the period from 27 December 2008 and 18 January 2009 provides the most recent example of high level enquiry [67]. Otherwise actions are usually challenged at the level of national governments.

${ }^{11}$ See for instance Case Concerning the Application of the Convention on the Prevention and Punishment of the Crime of Genocide (Bosnia and Herzegovina v Serbia and Montenegro) General List No 91 [2007] ICJ available at <http://www.icj-cij.org/docket/files/91/13685.pdf> accessed 26 April 2010. See also Shaw [46].
} 
territories in which they are deployed is more doubtful. The generally accepted view is that the Convention applies only in cases in which the military or police forces exercise effective control over the area in which they are operating. In Banković and Others $v$ Belgium and 16 Other Contracting States (dec.) [GC] no. 52207/99 ECHR 2001 it was held in the European Court of Human Rights that the fifteen states engaged in NATO bombing missions in Serbia were not bound by the Convention in respect of civilian deaths caused during an attack on Belgrade. British forces, on the other hand, have been held by the British courts in $R$ (Al-Skeini) v Secretary of State for Defence [2007] UKHL 26 to exercise sufficient control in a military detention centre in Basra in Iraq to require them to comply with the Convention but not in respect of the use of lethal force during operations outside their base. In the absence of a specific provision in a Status of Mission Agreement, as suggested above, it will not always be possible to establish liability on the part of participating states under the Convention for actions by their forces during crisis management missions.

There is an additional limitation on any form of state liability in respect of missions formally authorised by the United Nations Security Council under Chapter VII of the UN Charter. Article 103 of the Charter states explicitly that obligations under the Charter, which include those imposed on member states by the Security Council under Chapter VII, take precedence over all other international conventions. The result is that authorisation by the Security Council to carry out any specified operation or to use 'all necessary measures' to carry out a mission mandate may in effect legitimise methods that would otherwise constitute a violation of international human rights standards. In the recent British decision in the Al-Jedda v Secretary of State for Defence [2007] UKHL 58 case, for example, it was held that detention of a suspected insurgent in Iraq without recourse to a judicial hearing as required under the European Convention on Human Rights was legitimised by the relevant Security Council Resolution.

Further problems may arise from the decision by the European Court of Human Rights in the cases of Behrami v France and Saramati v France, Germany and Norway (dec.) [GC] no. 71412/01 and 78166/01 ECHR 2007 that in respect of operations carried out by the NATO-led KFOR forces in Kosovo under the auspices of the UN only the UN (not the individual states which contributed troops) can be held responsible for any violations. It is unclear whether this decision would extend to all operations authorised or recognised by the UN. The British courts have held in the Al-Jedda case that it does not apply to the operations by coalition forces in Iraq on the ground as these are not being carried out under the auspices of the UN, even though they have been authorised by a 
Security Council Resolution. In any event it would not apply to EU missions carried out without explicit reference to a Security Council Resolution.

These considerations emphasise the importance of prescribing in advance, wherever possible, the standards of conduct that are to apply during peacekeeping or crisis management missions. If the application of the standards required under the European Convention on Human Rights can be established by negotiation in a Status of Mission Agreement this would help to avoid these complex legal issues and make it clear that the EU is committed to these standards in all its missions.

\section{Political accountability}

Legal assessments and proceedings, as indicated above, are generally most useful as a means of establishing accountability for specific incidents. More general assessments of the merits of the initial decision to engage in a mission and of its success or otherwise in achieving its objectives and the accountability of those involved are essentially political. At this level the current procedures within the EU are less than satisfactory. The essential basis for effective accountability of this kind is the preparation and publication of the grounds for decisions and regular assessments of progress during and after deployment. But within the EU almost all the information on the grounds for decisions, assessments of progress and the final evaluations of each mission are regarded as confidential [3: 56].

Though there is an explicit provision in Article 21 of the Treaty of the EU that the European Parliament should be consulted by the Presidency and that the Presidency shall ensure that the views of the parliament are taken into consideration, this does not appear to operate effectively in respect of decision-making on individual missions. The

European Parliament has no input on decision making in respect of the European Security and Defence Policy, but should be informed on its developments. A recent study entitled Parliamentary Oversight of Civilian and Military ESDP Missions: The European and National Levels has revealed that there is no obligation for the Council to inform the European Parliament on developments prior to a decision [8]. It is possible for the European Parliament to adopt non-binding resolutions or recommendations during the decision making process and a Committee or political group of 40 Members of the European Parliament can transmit specific questions to the Council and the Commission. But according to this study only one question has so far been raised by an MEP. This concerned the EUFOR Althea mission and the capacity of mission personnel to comply with human rights standards and avoid abuses [8: 12]. 
In respect of 'post hoc' review or oversight after the launch of an operation, the study indicates that the European Parliament can adopt recommendations, resolutions, reports, visit troops and raise parliamentary questions [8: 13]. But though it is entitled to receive an annual report from the Council, it does not have the right of access to classified information [8: 18]. This means that any 'lessons learned' assessments prepared for the Council are not shared with the European Parliament. Finally though EU Special Representatives of each mission can report to the European Parliament they are not obliged to do so [8: 13].

The study also found a wide variation in the extent to which national parliaments are informed of and able to influence decisions on crisis management missions and to monitor their progress. In some EU countries, there are procedures for parliamentary approval of the foreign deployment of troops but there is rarely sufficient advance information for this to be an effective procedure. Additionally, there is little real opportunity for monitoring the progress or assessing the success of missions. Thus, effective parliamentary involvement in prior debate or approval or in subsequent monitoring or evaluations would require clearer procedures for reporting on the full range of issues, from early warning and mission planning to regular reports on progress. Closer cooperation between relevant committees and members of the European Parliament and national parliaments would be a further requirement. This is in stark contrast to the established procedures within the UN for regular reports by the Secretary General to the Security Council on progress and problems in peacekeeping and peace building missions.

The development of effective parliamentary and public accountability on EU crisis management policy and missions would require major changes in approach. Some of the possible measures that might be adopted with a view to facilitating political debate in the European Parliament and in member states include:

- preparation and publication of more detailed statements of the grounds for intervention in each crisis situation, the objectives and likely timescale for their achievement together with an assessment of the possible benefits and risks;

- the preparation and publication of regular annual reports on progress, problems, including reports on all incidents of abuse and the outcome of any disciplinary or legal proceedings, and the costs for each mission;

- the preparation and publication on the termination of each mission of independent expert assessments of the success or otherwise of the mission and of the lessons learned for the future;

- the development of procedures for regular committee hearings and debates in the European Parliament on these reports and assessments. 


\section{Options for reform}

The primary objectives for any amendments in established procedures should therefore be focused on both effective prevention and immediate investigation with appropriate sanctions insofar as is possible in the area in which the incident has taken place. In practice the two are closely linked. There are a number of possible approaches which might assist in meeting these objectives.

\section{(a) Relying on host state jurisdiction}

The provisions for ceding the otherwise exclusive jurisdiction of the contributing state to the host authorities are seldom used, unless the offence was committed by off duty personnel and had little to do with the performance of the mission. In some of the most serious cases of off-duty criminal conduct (rape, sexual exploitation or serious trafficking offences) there is still a tendency for the suspects to be removed as soon as possible from the jurisdiction of the host state.

The UN is currently attempting to develop a new and less restrictive international convention which would place greater reliance on host state jurisdiction. The Draft Convention on the Criminal Responsibility of United Nations Officials and Experts on Mission was prepared at the request of the Secretary-General in 2006 in response to increasing concerns over the incidence of sexual exploitation and abuse by UN peacekeepers and the resulting impact on the effectiveness of peacekeeping operations [65]. It would, if adopted, substantially increase the effective jurisdiction of the host countries, by providing for universal jurisdiction in respect of serious crimes committed during peacekeeping operations, and obliging all signatory states to cooperate in the investigation followed by extradition of those suspected to the country in which the crimes were committed.

There is, however, strong resistance to the adoption of this new convention and in particular to its application to military personnel. The initial draft explicitly excludes military personnel of national contingents engaged in a UN peacekeeping operation, anyone engaged in an operation under Chapter VII and anyone covered by immunity under a Status of Forces Agreement. This would in practice exclude almost everyone involved in a PSO. Nor would it extend to personnel engaged in EU or NATO missions operating independently of the UN. It therefore seems unlikely that a more general international convention designed to transfer jurisdiction to host states would prove any more acceptable or effective. 


\section{(b) Strengthened internal mission procedures}

An alternative approach would be to strengthen the capacity of mission commanders to deal with allegations of abuse in the area of deployment. Within the UN there is provision for internal boards of inquiry in respect of alleged misconduct by UN personnel in areas of deployment. The system is designed to allow an immediate inquiry into allegations of criminal or other abusive conduct. But the boards have no powers to adjudicate on criminal liability or to impose punishment other than repatriation or dismissal of the offender. And in many cases the rapid turnover of personnel or the fact that the alleged offender has already left the area means that cases cannot be effectively dealt with. Provisions have also been made in some recent UN operations for the appointment of ombudsmen or human rights monitors to receive complaints arising during PSOs, though they have thus far been restricted to carrying out investigations and making recommendations [62]. However, these systems are not, as currently operated, a satisfactory alternative to criminal proceedings in the home or host states.

The development of a more effective and meaningful process of this kind in the context of international missions would at the least involve the appointment of a mission ombudsman with authority to receive complaints and to monitor and report to those affected on the action taken by those in control of national contingents or units. To make it fully effective it would require individual participating states to transfer some disciplinary powers to the Operation Commander. Measures of this kind could be developed within the overall mandate, operation plan and rules of engagement for all participating states. Even if this proved acceptable, however, the system would remain open to the criticism that there would be no independent element in the process and that the 'internationals' would continue to be 'above the law' and to 'look after their own'.

\section{(c) Command responsibility}

A third possibility would be to develop a more demanding approach to command responsibility by imposing specific duties and sanctions on commanders of units within which criminal conduct or other abuses occur. The concept that superior officers can be held responsible for a failure to prevent offences by their subordinates has played an important part in the work of the International Criminal Tribunals for Yugoslavia and Rwanda [58]. It has also been provided for in the Statute of the International Criminal Court and can thus be relied on in States which have incorporated the list of crimes and forms of responsibility in their national law [59]. One advantage of this approach is that it highlights the importance of prevention at the level of operational planning and implementation rather than the punishment of offenders after the event when the damage 
to the reputation of the mission has already been done. But it is also subject to the lengthy delays and uncertainties in securing convictions in direct criminal proceedings in the national courts of alleged offenders.

\section{(d) The development of joint jurisdiction}

The drawback of these various approaches is that they fail to reflect the underlying nature and purpose of the deployment of international forces. The aim is not to supplant national judicial and criminal procedures but to assist in their development and effectiveness. A better way forward may be develop a form of joint investigation and adjudication.

The major objectives should be:

- speedy and independent investigation in the area where the incident occurred;

- formal proceedings, whenever possible, in the country of deployment;

- the involvement of representatives of the national authorities and local populations in both investigation and proceedings;

- trial procedures that are fair both for the accused and those directly affected.

These objectives might be implemented by the development of a variety of measures to satisfy the demands of independence and local input. One such measure would be the development of a more operationally investigative role for human rights monitors or ombudsmen. Allied to this would be the involvement of local criminal justice agencies in the investigative stages to assist in transparency. The development of formal tribunal procedures in the area of deployment would contribute to a partnership mindset that would empower the host population as actors in the reconstruction of their institutions rather than passive recipients of the actions of others over which they have no control.

Substantial contingents from contributing states are able to maintain their own internal disciplinary procedures for minor breaches of the rules of engagement and other abusive conduct and this is often the best method of ensuring that standards of conduct are observed. Where individual members of the local population have suffered it is important that they should be informed of the results of the processes and receive appropriate compensation. ${ }^{12}$ Responsibility for dealing with minor breaches by individuals from smaller contingents would rest with the mission commander. In such cases, and in respect of more serious incidents affecting the reputation of the mission as a whole, there may be a need for a more formal disciplinary tribunal at mission command

\footnotetext{
${ }^{12}$ Whilst not an aspect of international policing, the experience of the Police Ombudsman in Northern Ireland is that a significant proportion of complaints against the Police Service of Northern Ireland relate to failures in duty, of which failure to update victims is a major constituent part. This highlights the expectation on the part of victims to be kept informed and the part that having such information plays in bringing understanding and closure.
} 
level to emphasise the collective responsibility of the EU. To facilitate this, contributing states would have to surrender their exclusive jurisdiction, a challenge which has thus far been resisted.

The development of hybrid courts or joint trial procedures would be appropriate for the most serious or critical cases on which the reputation and acceptability of the mission in the eyes of the local population is at stake. This approach has been developed at an international level in what are referred to as hybrid tribunals in Bosnia-Herzegovina, Sierra Leone and East Timor with a view to increasing local accountability in the aftermath of conflict while providing a guarantee that the procedures will be fair and that there will be no suspicion of 'victor's justice' [41: 94]. The presentation of evidence in a public hearing in the area where the alleged abuse has taken place can help to convince the local population that the internationals are not above the law. The participation of their own national or international judges in the proceedings could likewise help to reassure defendants of the fairness of the trial procedures.

The focus so far has understandably been on justice or punitive outcomes but greater success is surely to be derived from never reaching that threshold. The development of a 'lessons learned' or 'best practice' culture would facilitate behavioural change. The UN created the Best Practices Section within the DPKO to achieve success in real time rather than merely through historic reporting [60]. The section manages and analyses relevant knowledge and having captured learning from the various peacekeeping operations, ensures that it is reported upon and delivered as part of training programmes [35]. It is imperative that mistakes, malpractice and unethical and criminal behaviour in peacekeeping operations are eliminated as far as possible and one method of reinforcing this would be the development of a learning culture. According to Cook et al organisational learning cannot take place without individual learning [13] and individual learning is only possible within the context of peacekeeping mission accountability where the structure of the mission supports interventions with personnel that reflect a range of outcomes from softer constructive managerial input to the harder disciplinary and criminal justice procedures. The creation of such a culture may be difficult - though not impossible - when one considers the eclectic mix of officers from differing policing backgrounds and styles and national caveats on their use and control whilst on mission. While best practice and lesson learning can, to a certain extent, be best achieved through structured post-mission debriefs, emerging difficulties can and should be dealt with in a real time and a degree of independence and oversight could be delivered through the offices of human rights monitors or ombudsmen as described above. 


\section{Conclusion}

Bayley outlines four essential reforms required in transforming the police in the context of ensuring adherence to democratic standards:

i. Accountability to the law rather than to the government;

ii. Protection of human rights, especially those rights that are required for the sort of political activity that is the hallmark of democracy;

iii. Accountability to people outside of the organisation who are specifically designated and empowered to regulate police activity;

iv. Operational priority to servicing the needs of individual citizens and private groups [5: 19-20].

It is not inconceivable to expect that those seeking to inculcate such operating standards ought to adhere to them in their own activities, not only domestically but also engaged in policing activities in third party states. There is a general reluctance at the level of national government to relinquish authority for citizens engaged on peacekeeping activities in an often alien environment with the ultimate desire to bring assistance to the citizens of that host state. Whilst the concerns that drive such thinking are understood, the competing drive for accountability does not seek to cast police officers performing duty on peacekeeping missions to the mercies of a justice system that does not similarly uphold fair trial guarantees and high standards in terms of evidential requirements. The proposals of this paper do not fly in the face of such safeguards but suggest a partnership approach of equal status that aims to ensure involvement and ownership along with acceptance of and confidence in eventual outcomes. 
Reference List

1. Activities of CoESPU. Available at http://coespu.carabinieri.it/Internet/Coespu/02_Activities.htm Accessed 27 November 2009.

2. Ahmad, O. (2008). Rotting Olives. Outlook India. 02 June 2008. Available at http://www.outlookindia.com/article.aspx?237577 Accessed 16 November 2009.

3. Arloth, J. \& Seidensticker, F. (2007). The ESDP Crisis Management Operations of the European Union and Human Rights. Berlin: German Institute for Human Rights.

4. Barnett, A. \& Hughes, S. (2001). British Firm Accused in UN Sex Scandal. The Guardian. 29 July 2001. Available at http://www.guardian.co.uk/world/2001/jul/29/unitednations> accessed 18 November 2009.

5. Bayley, D. H. (2006). Changing the Guard: Developing Democratic Police Abroad. Oxford: Oxford University Press.

6. Bayley, D. H. and Perito, R. M. (2010). The Police in War: Fighting Insurgency, Terrorism and Violent Crime. Boulder: Lynne Reiner Publishers.

7. Bayley, D. H. and Shearing, C. D. (2001). The New Structure of Policing: Description, Conceptualization, and Research Agenda. Washington: National Institute of Justice.

8. Born, H. (2007). Parliamentary Oversight of Civilian and Military ESDP Missions: The European and National Levels. Brussels: European Parliament.

9. Call, C. \& Barnett, M., (2000). Looking for a Few Good Cops: Peacekeeping, Peacebuilding and CIVPOL. In Holm, T. T. \& Eide, E. B. (Eds), Peacebuilding and Police Reform. London: Frank Cass.

10. Canadian Defence Academy. (2010). IADC Peace Support Operations Seminar. Washington. 20-29 January 2010. Available at http://www.jid.org/college/seminars/content/Peace\%200ps/ppt/Thomas.ppt Accessed 20 April 2010.

11. United Nations Office on Drugs and Crime. (1992). Compendium of United Nations Standards and Norms in Crime Prevention and Criminal Justice. Available at http://www.unodc.org/unodc/en/justice-and-prisonreform/compendium.html accessed on 6 January 2011.

12. Council of European Union. Conduct of Operations Unit, Interim Civilian Planning and Conduct Capability - on file.

13. Cook, J. A., Staniforth, D. \& Stewart, J. (1997). The Learning Organization in The Public Services. Aldershot: Gower Publishing.

14. Council of the European Union. (2001). Civilian Capabilities Commitment Conference. Brussels, 19 November 2001. See CEU 15193/01 and 
http://www.consilium.europa.eu/uedocs/cmsUpload/COMMITMENT\%20CONF ERENCE\%20MINISTERIAL\%20DECLARATION\%2022.11.04.pdf Accessed 24 November 2009.

15. Council of the European Union. (2005). Generic Standards of Behaviour for ESDP Operations. CEU 8373/3/05 REV 3. <http://register.consilium.europa.eu/pdf/en/05/st08/st08373-re03.en05.pdf> accessed 26 April 2010

16. Council of the European Union. (2006). Conclusions on Gender Equality and Gender Mainstreaming. CEU 14779/06 (PRESSE 302).

17. Council of the European Union. (2006). Mainstreaming Human Rights across CFSP and other EU Policies. CEU 10076/06.

18. Dixon, M. (2007). Textbook on International Law. Oxford: Oxford University Press.

19. Duffey, T. (2000). Cultural Issues in Conflict Resolution. In Woodhouse, T. \& Ramsbotham, O. (Eds), Peacekeeping and Conflict Resolution. London: Frank Cass.

20. Dwan, R. (Ed). (2003). Executive Policing: Enforcing the Law in Peace Operations. Oxford: Oxford University Press.

21. European Council Meeting (2000) Presidency Conclusions. http://www.consilium.europa.eu/ueDocs/cms_Data/docs/pressData/en/ec/00400r1.\%20ann.en0.htm Accessed 12 April 2010.

22. European Gendarmerie Force Website. http://www.eurogendfor.eu Accessed 12 April 2010.

23. European Parliament. (2000). Presidency Report on Strengthening the Common European Security and Defence Policy http://www.europarl.europa.eu/summits/fei2_en.htm Accessed 27 November 2009.

24. G8 Action Plan. (2004). Available at http://www.g8.utoronto.ca/summit/2004seaisland/peace.html Accessed 27 November 2009.

25. Goldsmith, A. \& Lewis, C. (Eds). (2000). Civilian Oversight of Policing: Governance, Democracy and Human Rights. Oxford: Hart Publishing.

26. Goldsmith, A. \& Sheptycki, J. (Eds). (2007). Crafting Transnational Policing: Police Capacity-building and Global Policing Reform. Oxford: Hart Publishing.

27. Goldsmith, A. (2005). Police Reform and the Problem of Trust. Theoretical Criminology 9, 443.

28. Grieve, J., Harfield, C. \& and McVean, A. (2007). Policing. London: Sage Publications. 
29. Hadden, T. (Ed). (2009). A Responsibility to Assist: Human Rights Policy and Practice in European Union Crisis Management Operations. Oxford: Hart Publishing.

30. Hansen, A. S. (2002). From Congo to Kosovo: Civilian Police in Peace Operations. Oxford: Oxford University Press.

31. Hartz, H.A. (2000). CIVPOL: The UN Instrument for Police Reform. In Holm, T.T. \& Eide, E.B. (Eds). Peacebuilding and Police Reform. London: Frank Cass.

32. Hills, A. (2009). Policing Post-Conflict Cities. London: Zed Books.

33. Holm, T.T. \& Eide, E. B. (Eds). (2000). Peacebuilding and Police Reform. London: Frank Cass.

34. Horton, S. (2007). War Profiteering and Other Contractors Crimes Committed Overseas. 19 June 2007. Committee on the Judiciary: Subcommittee on Crime, Terrorism and Homeland Security. Available at http://judiciary.house.gov/hearings/June2007/Horton070619.pdf Accessed 20 April 2010.

35. Howard, L. M. (2008). UN Peacekeeping in Civil Wars. Cambridge: Cambridge University Press.

36. Human Rights Watch. (2008) Kosovo: EU Should Ensure International Mission Accountable. Available at http://www.hrw.org/en/news/2008/03/09/kosovo-eu-shouldensure-international-mission-accountable Accessed 24 November 2009.

37. Joint Doctrine and Concepts Centre. (2004). The Military Contribution to Peace Support Operations. $2^{\text {nd }}$ Ed. Swindon: JDCC.

38. Lewis, C. (2000). The Politics of Civilian Oversight: Serious Commitment or Lip Service? In Goldsmith, A. \& Lewis, C. (Eds). Civilian Oversight of Policing: Governance, Democracy and Human Rights. Oxford: Hart Publishing.

39. Lynch, C. (2002). Austria is Said to Aid Flight of Suspect; U.N. Officials Assail Thwarting of Probe. Washington Post. 6 March 2002.

40. MEJA Expansion and Enforcement Act 2007 available at http://www.govtrack.us/congress/bill.xpd?bill=h110-2740 Accessed 20 April 2010.

41. Mendez, P. K. (2009). The New Wave of Hybrid Tribunals: A Sophisticated Approach to Enforcing International Humanitarian Law or an Idealistic Solution with Empty Promises? Criminal Law Forum 20, 53.

42. Mobekk, E. (2005). Identifying Lessons in United Nations International Policing Missions, Geneva: Centre for the Democratic Control of Armed Forces.

43. Perito, R. M. (2003). The American Experience With Police in Peace Operations, Clementsport: The Canadian Peacekeeping Press. 
44. Proceedings of the International Post-Conflict Policing Operations Conference: Enhancing Co-ordination and Effectiveness, January 2004 Wilton Park and University of Bradford, copy on file with the author.

45. Shaw, M. N. (2008). International Law. $6^{\text {th }}$ Ed. Cambridge: Cambridge University Press.

46. Shaw, M. (2007). The International Court of Justice: Serbia, Bosnia, and Genocide. Open Democracy. 28 February 2007. Available at $<\mathrm{http}: / / \mathrm{www}$.opendemocracy.net/globalizationinstitutions_government/icj_bosnia_serbia_4392.jsp Accessed 26 April 2010.

47. The Transparency and Accountability in Security Contracting Act of 2009 available at http://www.govtrack.us/congress/bill.xpd?bill=h111-2177 Accessed 20 April 2010.

48. UN News Centre. (2007). Interim Report on Shootings in Kosovo Cities Romanians Attached to UN Police Unit. Available at http://www.un.org/apps/news/story.asp?NewsID=22240\&Cr=kosovo\&Cr1 $=$ Accessed on 24 November 2009.

49. UN News Centre. (2009) UN Peacekeepers Involved in Abuse are Being Punished, World Body Says. http://www.un.org/apps/news/story.asp?NewsID=32857 Accessed 16 November 2009.

50. United Nations Department of Peace Keeping Operations. (2009). Police Contributing Countries See Lasting Benefits of UN Deployment. United Nations Police Magazine. $3^{\text {rd }}$ Edition. http://www.un.org/Depts/dpko/police/pdf/UNPolice mag3.pdf Accessed on 3 November 2010.

51. United Nations Department of Peacekeeping Operations. (2003). Directives for Disciplinary Matters Involving Military Members of National Contingents. PKO/CPD/DDCPO/2003/001.

52. United Nations Department of Peacekeeping Operations. (2003). Directives for Disciplinary Matters Involving Civilian Police Officers and Military Observers, DPKO/CPD/DDCPO/2003/001 DPKO/MD/03/00994 available at http://www.un.org/en/peacekeeping/info/documents/disciplinary_issues.pdf Accessed 18 November 2009.

53. United Nations Department of Peacekeeping Operations. Public Information Guidelines for Allegations of Misconduct Committed by Personnel of UN Peacekeeping and Other Field Missions. DPKO/MD/03/00996 DPKO/CPD/DPIG/2003/001

54. United Nations Office of the High Representative for the Least Developed Countries, Landlocked Developing Countries and Small Island Developing States. http://www.unohrlls.org/en/ldc/related/62 Accessed 16 November 2009. 
55. United Nations Police Division. Minimum Police Recruitment Requirements. Available at http://www.un.org/en/peacekeeping/sites/police/qualities.shtml Accessed 18 November 2009.

56. United Nations. (1994). Statute of the International Criminal Tribunal for Rwanda. S/RES/955.

57. United Nations. (1946). Convention on the Privileges and Immunities of the United Nations. A/RES/22 A (I). Available at http://www.unog.ch/80256EDD006B8954/(httpAssets)/C8297DB1DE8566F2C1 256F2600348A73/\$file/Convention\%20P\%20\&\%20I\%20(1946)\%20-\%20E.pdf Assessed on 6 January 2011.

58. United Nations. (1993). Statute of the International Tribunal for the Prosecution of Persons Responsible for Serious Violations of International Humanitarian Law Committed in the Territory of the Former Yugoslavia since 1991. UN Doc S/25704.

59. United Nations. (1998). Rome Statute of the International Criminal Court. A/CONF 183/9

60. United Nations. (2000). Report of the Panel on United Nations Peace Operations. A/55/305-S/2000/809

61. United Nations. (2000). Security Council Resolution on Women and Peace and Security. S/RES/1325.

62. United Nations. (2005). Working Paper on the Accountability of International Personnel Taking Part in Peace Support Operations. UN Doc E/CN.4/Sub.2/2005/42.

63. United Nations. (2008). Peacekeeping Operations: Principles and Guidelines (Capstone Doctrine) available at <http://www.peacekeepingbestpractices.unlb.org/Pbps/Library/Capstone_Doctrin e_ENG.pdf> accessed 20 April 2010.

64. United Nations. (2009). Human Rights in Palestine and Other Occupied Arab Territories: Report of the United Nations Fact Finding Mission on the Gaza Conflict. A/HRC/12/48

65. United Nations. Ensuring the Accountability of United Nations Staff and Experts on Mission with Respect to Criminal Acts Committed in Peacekeeping Operations. A/60/980

66. United Nations. Functions and Organization of Formed Police Units in United Nations Peacekeeping Operations. DPKO/PD/2006/00060. Available at http://www.un.org/Depts/dpko/dpko/pub/yir2008.pdf Accessed on 3 November 2009. 
67. Wilber, D. Q. (2010). Charges Dismissed Against Blackwater Guards in Iraq Deaths. Washington Post. 1 January 2010.

68. Woodhouse, T. \& Ramsbotham, O. (Eds). (2000). Peacekeeping and Conflict Resolution. London: Frank Cass. 